\title{
INVESTIGATION ACTIVITY ABOUT A COLLAPSED STEEL STRUCTURE SUBJECTED TO A REAL FIRE Fire scenarios and structural behaviour of real steel structure
}

\author{
Iolanda Del Prete ${ }^{\mathrm{a}}$, Nicola Di Fiore ${ }^{\mathrm{a}}$, Emidio Nigro $^{\mathrm{a}}$, Luca Ponticelli $^{\mathrm{b}}$, Giovanni Di Stefano ${ }^{\mathrm{c}}$ \\ ${ }^{\mathrm{a}}$ Department of Structures for Engineering and Architecture, University of Naples Federico II, Naples, Italy \\ ${ }^{b}$ Ministry of the Interior - Italian Fire Services, Central Directorate for Fire Prevention and Civil Defense, Capanelle \\ (Rome), Italy \\ ${ }^{c}$ Ministry of the Interior - Italian Fire Services, Fire Headquarters, Ragusa, Italy
}

\begin{abstract}
The paper describes the behaviour ofa real steel structure collapsed under a fire event. 3D structural analyses were performed with SAFIR program (J-M Franssen, 2005). Different modellingare implemented with some fire load models and analyses of thebehaviour of the whole structure. The main purpose of this work was to investigate the failure types of a warehouse structure under fire conditions. Different fire conditions were applied to the steel frame sections, with ISOcurve (ISO EN 834-8:2002) and zone model approach. The analyses show that with unprotected steel sections, horizontal structures are more critical than columns. Trough applying a performance basedapproach,structure has 30 minutes of fire resistance.
\end{abstract}

Keywords:fire safety, structural fire behaviour, finite element analysis, fire survey

\section{INTRODUCTION}

The determination of the causes of a real fire requires extremely complex investigations, because fire tends to destroy or make unrecognizable elements that could be traced back into its origin and development. In Ragusa (Sicily) a fire caused the collapse of cardboard production manufactory. The fire was extinguished thanksto the operation of Fire Headquarters of Ragusa. A firefighter team came in for the fire shut down operations. Immediately after fire extinguishing phase, fire brigade team made a survey, to verify manufactory damages, burned and unburned materials. The Fire Headquarters activity directed to reach certain knowledge about events with trigger causes; this aspect is very useful for research purposesbecause this real fire situation allows calibrating both fire load modelling and structural behaviour of the whole manufactory.

The contents of the paper consist infire brigade survey, and the consequent numerical analyses, which are made with real scenario data.

Firstlyis applied ISO 834 standard curve to all elements to evaluate hyperstatic action types, because they are causedby temperature rise, and to simulate theright boundary conditions.

Afterwardsis implemented a natural fire scenario to simulate the time-temperature trend and to evaluate displacement range and stress characteristics, to study the behaviour of real collapse.

\section{FIRE BRIGADE INVESTIGATIVE REPORT}

The report of Fire Brigade includes some aspects, which was investigated during survey (Nigro et al, 2013):

- causes of fire ignition;

- structural damages (safety and serviceability);

- burned and unburned materials (fuel load).

A probably cause of ignition was a little burner, usedin the application of polymeric glue in cardboard packaging activity.This burner, left on during night, caused very fast flames propagation. Afterwards the flames reach every material insightand fire was totally developed: the fire extinction required considerable efforts. 
The work of the FireGroup of University of Naplesstarts from the analysis of the contents of the Fire Brigade Report, such asthe fuel load,the geometry of whole structure, the mechanical properties of the structural elements.

The buildinghas a surface of $26.00 \mathrm{~m} \times 40.10 \mathrm{~m}$, delimited on two sides by brick walls and with sheet metal on the other sides (Fig. 1 - Fig. 2).

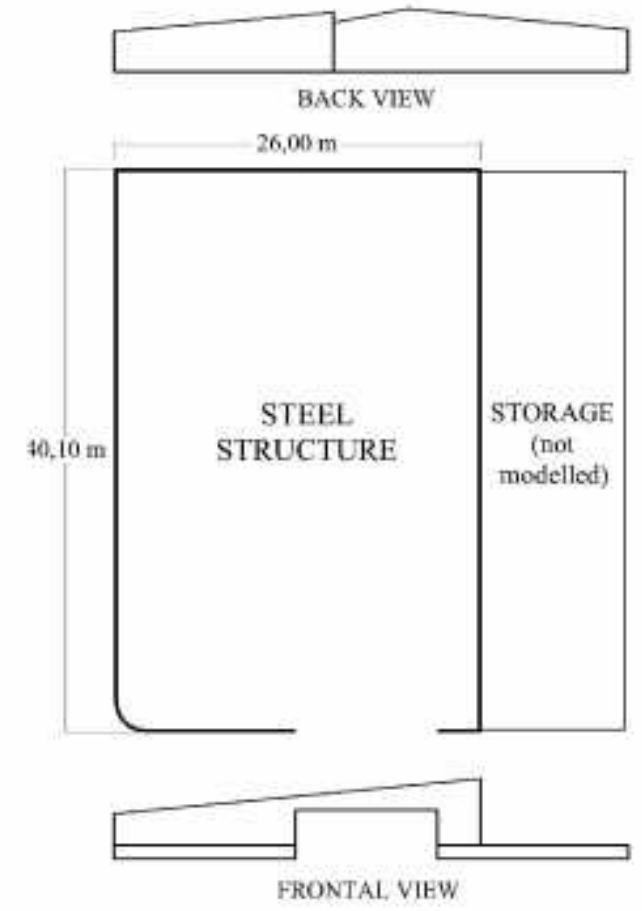

Fig. 1 Manufactory planimetry

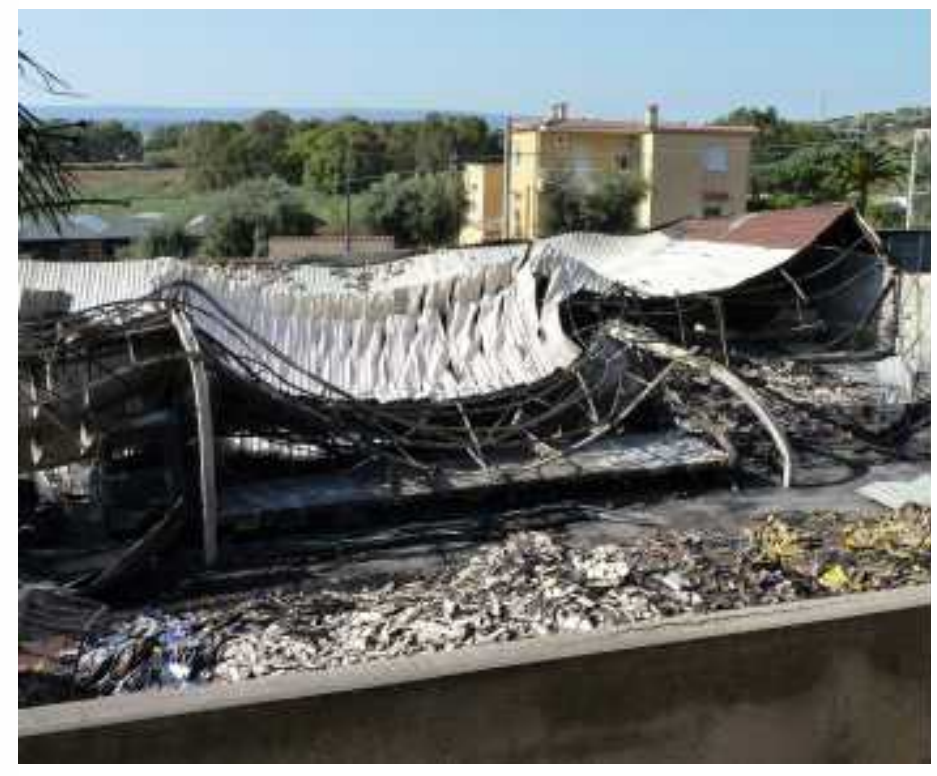

Fig. 2 Collapsed structure

\subsection{Fire load survey}

The results of the fuel load-inventory activity lead to estimate a fuel load of $580 \mathrm{MJ} / \mathrm{m}^{2}$, which is lower than theexpectancy for this occupancy type (Nigro et al., 2013), based on the data provided in EN 1991-1-2 or inliterature values (CIB W14 Workshop Report, 1986; Handbook of Fire Protection Engineering, 2002).

\begin{tabular}{|l|c|c|c|c|c|}
\cline { 2 - 6 } \multicolumn{1}{c|}{} & $\begin{array}{c}\text { heat of } \\
\text { combustion } \\
{[\mathrm{MJ} / \mathrm{kg}]}\end{array}$ & $\begin{array}{c}\text { quantity } \\
{[-]}\end{array}$ & $\begin{array}{c}\text { weight each } \\
\text { one }[\mathrm{kg}]\end{array}$ & $\begin{array}{c}\text { total weight } \\
{[\mathrm{kg}]}\end{array}$ & $\begin{array}{c}\text { Total fireload } \\
{[\mathrm{MJ}]}\end{array}$ \\
\hline Wood material & 18.42 & 20 & 700 & 14000 & 257902 \\
\hline Cardboard for packaging & 17.00 & 20000 & 0.60 & 12000 & 204000 \\
\hline Glue (vinyl acetate) & 23.06 & & & 1000 & 23060 \\
\hline Diesel fuel & 43.16 & $2 \mathrm{mc}$ & & 1820 & 78551 \\
\hline Truck (Haukur, Ingason, 2009) & & & & & 12000 \\
\hline Workbench (wood) & 16.74 & 2 & 150 & 300 & 5021 \\
\hline Workbench (steel) & 15.21 & 2 & 110 & 200 & 3347 \\
\hline Total fuel load [MJ] & \multicolumn{3}{|c|}{583882} \\
\hline
\end{tabular}

Table 1 - Fire load inventory

This fire load is affected byuncertainty, because thesurvey conducted by the firefighter is notaimed tonumerical simulation, but it has to provide just a roughly idea of the fuel load stored in the building at the time of the fire event. Thesurvey is made immediately after the fire event.Theweight of burned materials is calculated basing on the observation of unburned material. 


\subsection{Material properties and structural survey}

The building has a surface of $1044 \mathrm{~m}^{2}$. The height ranged between 3,5 $\mathrm{m}$ and 5,10 $\mathrm{m}$. The roof of this steel structureis made with a steel deckconnected to truss secondary beams. The latter are connected to truss main girders. The steel roof was jointed on brick walls, along two sides, and was fixed on HEA160 vertical columns.

The brick walls (along 2 of 4 sides)play a significant role infire compartmentation, therefore they are taken into account in the definition of the fire compartment, but they are not modelled in the structural model, given their higherfire resistancethan steel elements.

Table 2 shows the steel elements properties and Fig. 3 shows a scheme of the analyzed structure.

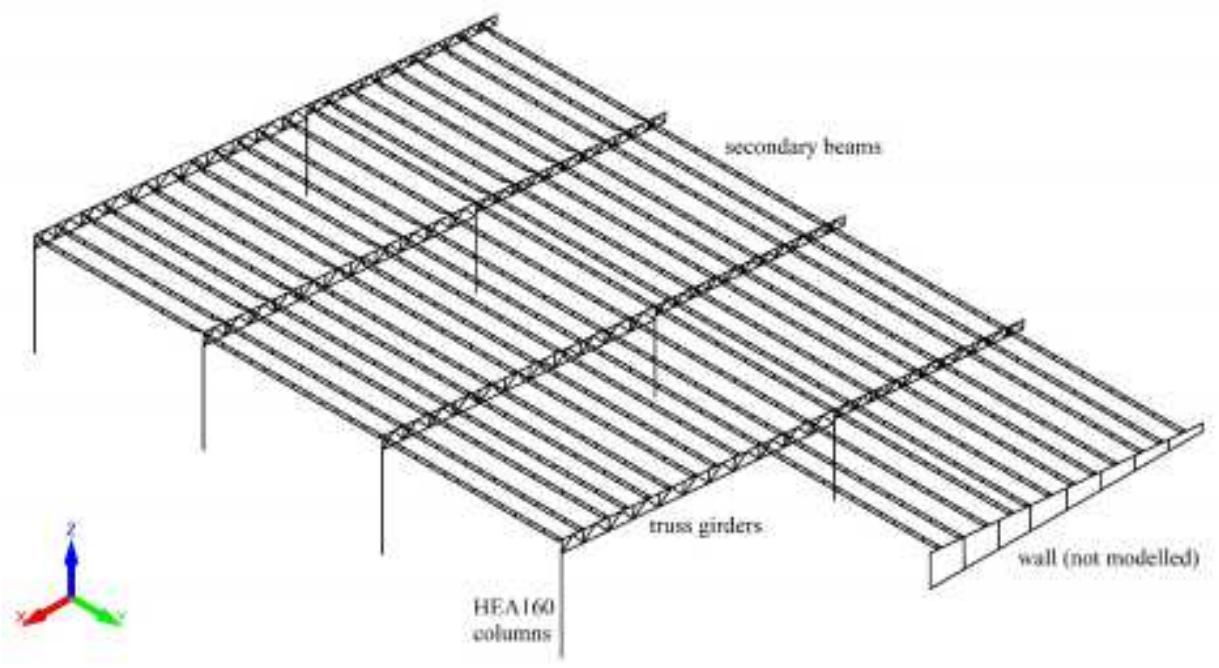

Fig. 3 - Scheme of the analyzed structure

\begin{tabular}{|c|c|c|c|c|c|c|c|c|}
\hline structural use & \multirow{2}{*}{$\begin{array}{c}\text { section } \\
\text { type }\end{array}$} & $\mathbf{f y}$ & $\mathbf{c l a s s}$ & $\mathbf{A}$ & $\mathbf{I x}$ & $\mathbf{I y}$ & $\mathbf{I}_{\max }$ & $\bar{\lambda}_{\max }$ \\
\cline { 6 - 10 } & {$[\mathrm{Mpa}]$} & $\mathbf{f i r e})$ & {$\left[\mathrm{mm}^{2}\right]$} & {$\left[\mathrm{mm}^{4}\right]$} & {$\left[\mathrm{mm}^{4}\right]$} & {$[\mathrm{m}]$} & $($ cold $)$ \\
\hline columns & HEA160 & 275 & 1 & 3877 & $1.67 \mathrm{E}+07$ & $6.16 \mathrm{E}+06$ & 5,08 & 1,02 \\
\hline $\begin{array}{c}\text { truss girders-primary } \\
\text { beams } \\
\text { (top chord and bottom } \\
\text { chord) }\end{array}$ & $30 \times 60 \times 2$ & 275 & 1 & 344 & $1.60 \mathrm{E}+05$ & $5.32 \mathrm{E}+04$ & 15,10 & 0,65 \\
\hline $\begin{array}{c}\text { truss girders-primary } \\
\text { beams } \\
\text { (web) }\end{array}$ & $30 \times 40 \times 2$ & 275 & 1 & 264 & $5.90 \mathrm{E}+04$ & $3.74 \mathrm{E}+04$ & 0,95 & 0,46 \\
\hline $\begin{array}{c}\text { secondary beams } \\
\text { (top chord) }\end{array}$ & $30 \times 60 \times 2$ & 275 & 1 & 344 & $1.60 \mathrm{E}+05$ & $5.32 \mathrm{E}+04$ & 10,00 & 4,63 \\
\hline $\begin{array}{c}\text { secondary beams } \\
\text { (bottom chord) }\end{array}$ & $35 \times 3$ & 275 & 1 & 105 & $7.88 \mathrm{E}+01$ & $1.07 \mathrm{E}+04$ & 10,00 & 1,48 \\
\hline $\begin{array}{c}\text { secondary beams } \\
\text { (web) }\end{array}$ & $35 \times 20 \times 2$ & 275 & 1 & 204 & $1.29 \mathrm{E}+04$ & $3.18 \mathrm{E}+04$ & 0,25 & 0,43 \\
\hline $\begin{array}{c}\text { beams on the wall } \\
\text { (along one smallest side) }\end{array}$ & $40 \times 80 \times 2$ & 275 & 4 & 464 & $3.90 \mathrm{E}+05$ & $1.31 \mathrm{E}+05$ & 2,00 & 0,68 \\
\hline
\end{tabular}

Table 2 - Structural frames

\section{FIRE SCENARIO AND STRUCTURAL MODEL: NUMERICAL SIMULATION}

The fire models aredefined according to EN 1991-1-2.Both standard ISO 834 standard curve and natural fire curvesare implemented.Cross-sectional thermal analyses and three-dimensional mechanical analyses are conducted witha Finite Element (FE) software, SAFIR 2011, developed at the University of Liegi (J-M. Franssen, 2005). The mechanical analyses enabled to take into account the indirect actions due to the elements thermal restrain, stress redistributions and global collapse. 


\subsection{Study of joint's beahviour: structural model under standard ISOfire.}

Since inSAFIR, when equilibrium is not guaranteed by congruity equations, the analysis stops and is not possible to take into account progressive collapse, in order to testthe reliability of structural model, a parametric analysisis conducted referring to the ISO 834 standard fire exposure. The failure mode seems to be very much dependent onthe jointtype between columns and truss girders.Differentjoint constraintsprovide different time of resistance (table 3).

\begin{tabular}{|c|c|c|c|c|c|}
\hline $\begin{array}{c}\text { analysis } \\
\text { num }\end{array}$ & type & $\begin{array}{c}\mathrm{M}_{\mathrm{x}} \\
\text { constr. }\end{array}$ & $\begin{array}{c}\mathrm{M}_{\mathrm{y}} \\
\text { constr. }\end{array}$ & $\begin{array}{c}\text { time } \\
\text { collapse }\end{array}$ & $6]$ \\
\hline 1 & $\begin{array}{l}\text { central row } \\
\text { edge row }\end{array}$ & $\begin{array}{l}x \\
\checkmark\end{array}$ & $\begin{array}{l}\checkmark \\
\checkmark\end{array}$ & $637 \mathrm{~s}$ & 8 \\
\hline 2 & $\begin{array}{l}\text { central row } \\
\text { edge row }\end{array}$ & $\begin{array}{l}x \\
\checkmark\end{array}$ & $\begin{array}{l}x \\
\checkmark\end{array}$ & $463 \mathrm{~s}$ & \\
\hline 3 & $\begin{array}{l}\text { central row } \\
\text { edge row }\end{array}$ & $\begin{array}{l}\checkmark \\
\checkmark \\
\end{array}$ & $\begin{array}{l}\checkmark \\
\checkmark\end{array}$ & $582 \mathrm{~s}$ & central tow \\
\hline 4 & $\begin{array}{l}\text { central row } \\
\text { edge row }\end{array}$ & $\begin{array}{l}\checkmark \\
x \\
\end{array}$ & $\begin{array}{l}\checkmark \\
\checkmark\end{array}$ & $302 \mathrm{~s}$ & ederen wow \\
\hline
\end{tabular}

Table 3 - Collapse times with different joint constraints

In case of standard fire, the structural model shows a global failure, characterized by very large deflection of primary and secondary girders, the instability of the secondary roof beams, the deflection of the columns inward.

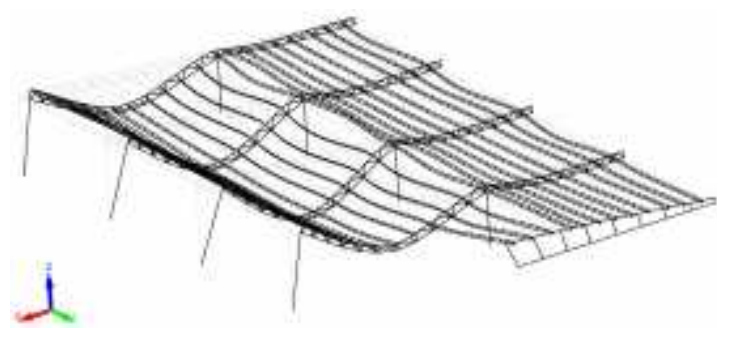

Fig. 4 - Deformed structure (scale 1x - ISO fire- 613s)

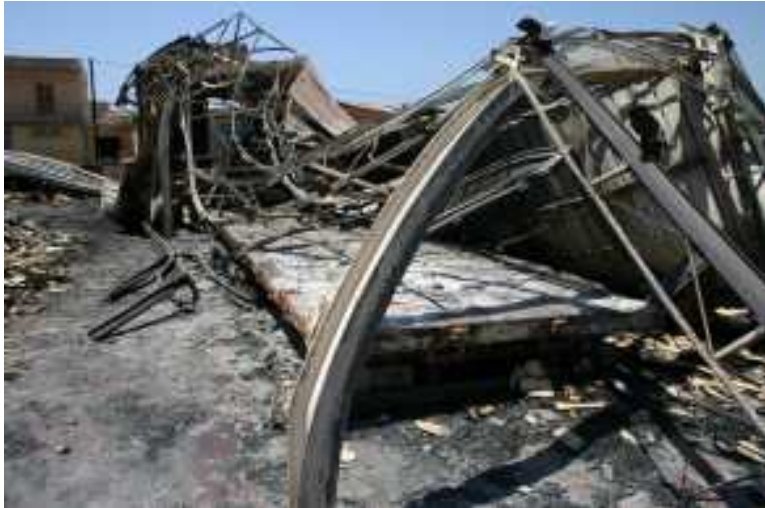

Fig. 5 -Collapsed Columns

The Fig. 4 and Fig. 5 show that SAFIRis able to provide qualitatively the failure mode of the structure, with the internal joints which are modelled as shown in the row 1 in Table 3.In this case the ISO 834 standard fire causesthe failure in $10 \mathrm{~min}$.

\subsection{Structural behaviour in case of natural fire}

The natural fire model implemented for this work is a one zone model, it is obtained through the softwareOZone (J-F. Cadorin, 2003).This softwareprovides zone models according to EN 1991-1-2. The natural fire modelling enabled to assessthe effects of the total energy of the real fire load and of the cooling phase. In the EN 1991-1-2 (Annex E), fire load densities for different occupancies are indicated. In this real case the fire load isestimated with a survey method, indications about load materials (Table 1) are used to implement a $\mathrm{t}^{2}$ curve for each type of material. The RHR curve is modelled as the sum of single RHR curve of each type of material; the calorific power released, included the cooling phase whichis showed in Fig. 6, with generated temperatures in Fig. 7. 


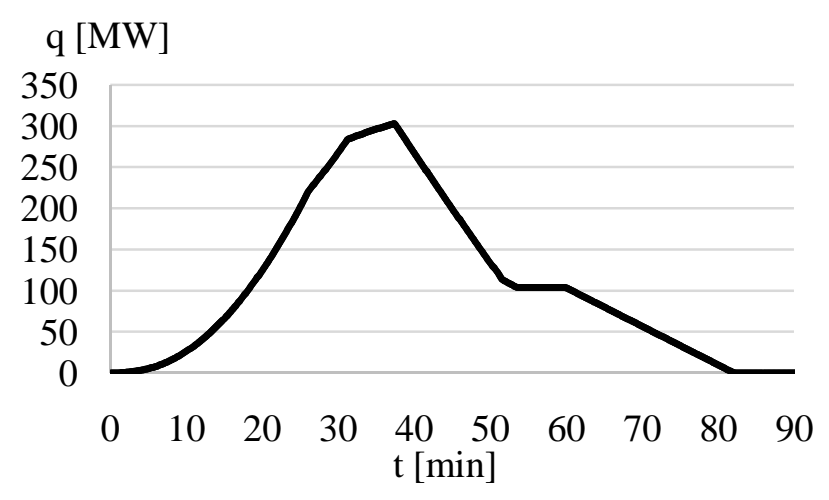

Fig. 6 - RHR curve

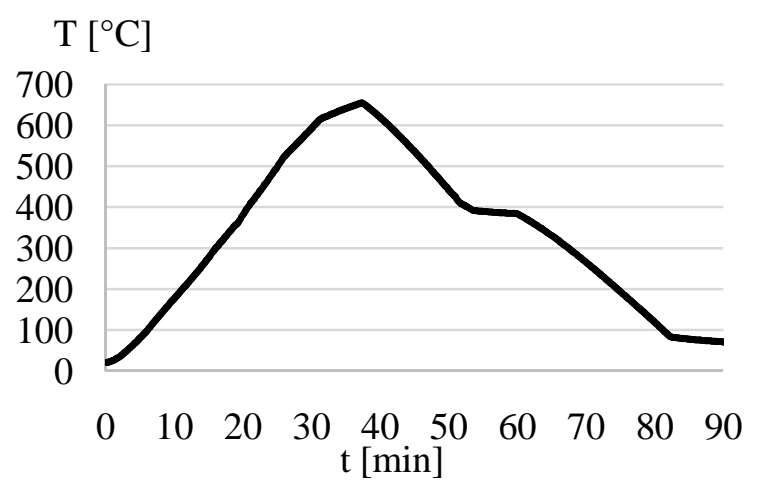

Fig. 7- Environment temperatures

In Fig. 8 the resistances of some elements belonging to the secondary beams are showed,there is a decrease due to the increasing temperature. This beams are 30x60x2 dimensions and are used for top chord of secondary beams, their effective length is $2 \mathrm{~m}$, but there are not jointed in the cover plane direction. In the Fig. 7 corresponding time-resistances are reported for different buckling length $\left(1_{0}\right)$ values. It is clear for these elements that the crisis is reached alongthe cover plane; in the Fig. 8 is showed time-temperatures trend of these elements.

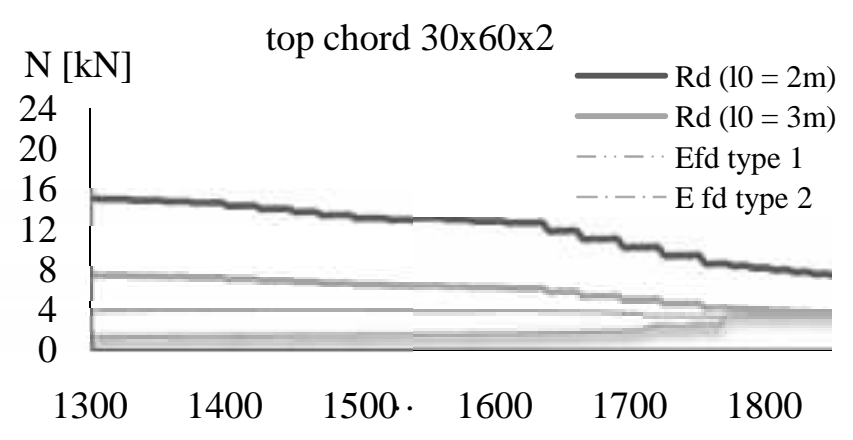

Fig. $7-\mathrm{E}_{\mathrm{fd}}-\mathrm{R}_{\mathrm{d}}$ Resistance comparison with different buckling lengths and stress values

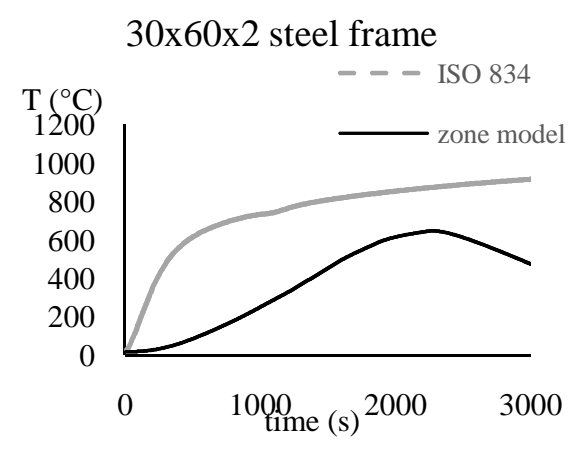

Fig. 8- Beam temperature: comparison ISO834-zone model

The buckling instability crisisisin evidencefrom survey details (Fig. 9) and is also well simulated in the $3 \mathrm{~d}$ model structure (Fig. 10).

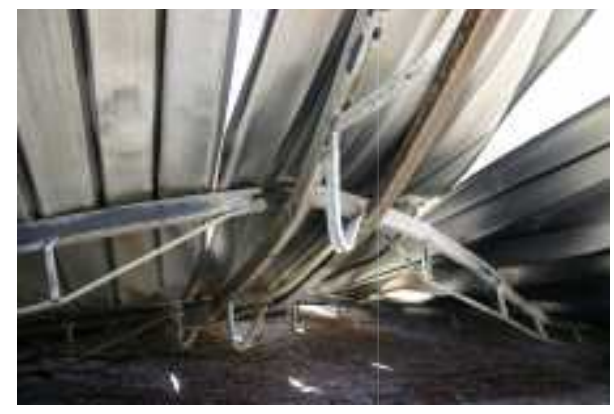

Fig. 9 - Secondary beams instability top chord

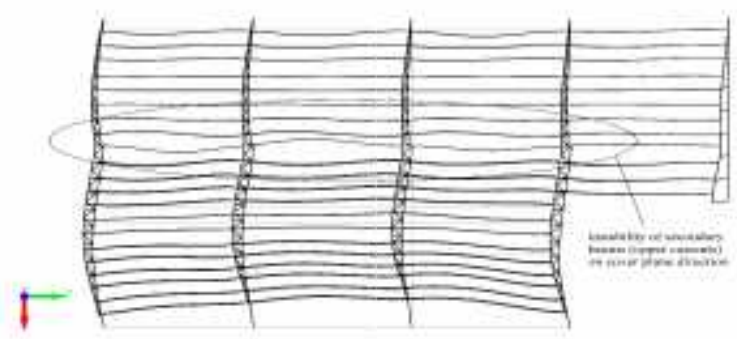

Fig. 10 - Instability of secondary beams on cover plane direction (1766s)

Several elementsdo notachieve the critical temperature, but theirstructural failure can be reasonably justified throughthe global buckling of the secondary beams, which carry on the primary beams and the head of the columns. In the Fig 11 are showed the primary beams displacements, and in Fig. 12 is possible to appreciate the columns deformations at the end time (about 30 minutes). 


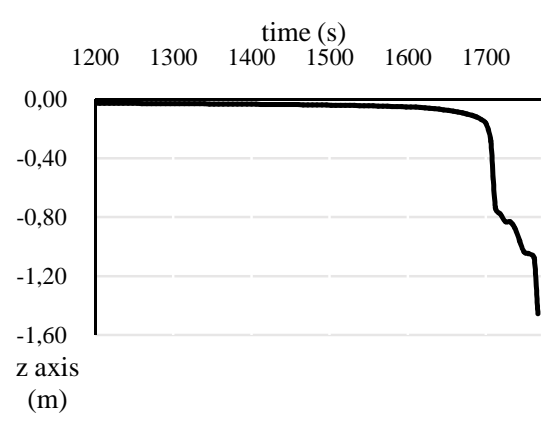

Fig. 11 Truss girders - midspan displacement

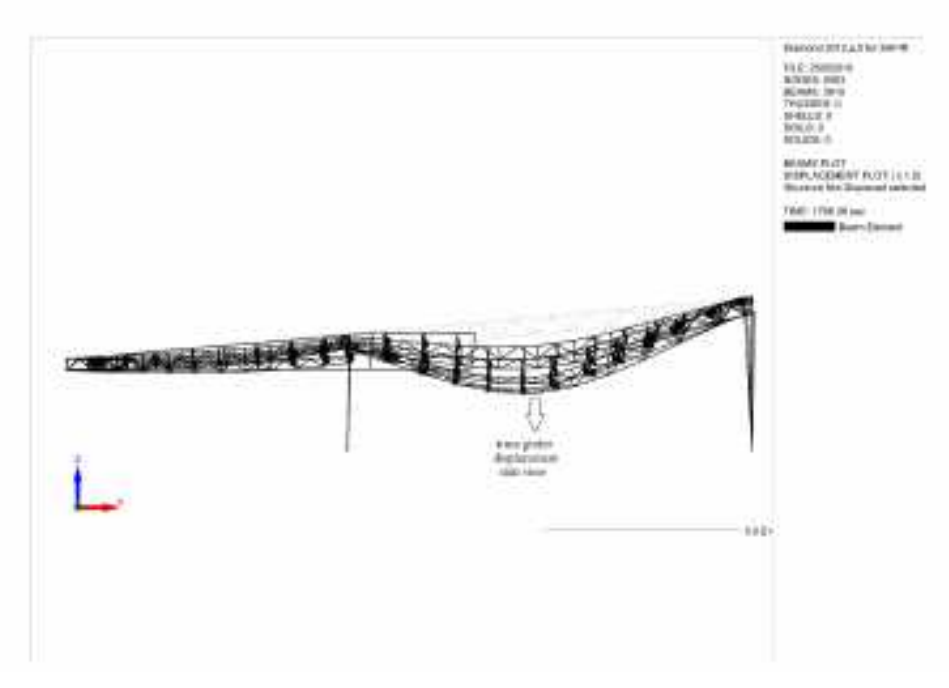

Fig. 12 Deflection at $1766 \mathrm{~s}$ (displacement x1.5 - Side view)

\section{CONCLUSIONS}

The following conclusions can be drawn at the end of the analysis results:

- with an advanced structural modelling can be take in account stress redistributions during fire, which are much influenced by internal joints conditions;

- $\quad 3 \mathrm{~d}$ model structure has a global collapse both with natural fire scenario and with ISO standard curve; the behaviour is also similar, clearly with different values of deformations and time of failure (30 min vs $10 \mathrm{~min}$ );

- with advanced 3d structural modelling and a most probable fire scenario itis possible to simulate global collapse in the model like survey data showed;

- a future development will be the comparison between results just showed and a travelling fire model to analyse temperature gradient and its effects on the structural beahviour.

\section{REFERENCES}

CIB W14 Workshop Report, 1986, Design guide - structural fire safety, Fire Safety Journal,1986, pages77137.

EhabZalok, James Eduful, 2013, Assessment of fuel load survey methodologies and its impact on fire load data, , Department of Civil and Environmental Engineering, Carleton University, Ottawa, Canada.

Eurocode 1 Actions on structures - Part 1-2: General Actions - Actions on structures exposed to fire.

Eurocode 3 Design of steel structures Part 1-2: General Rules - Structural fire design.

E. Nigro, G. Cefarelli, F.M. Mazzolani, I. Del Prete, F. Notaro, L. Ponticelli, Fire Brigade Reports and investigation in Italy: procedures statistics and real fire description, 2013- COST TU0904 - Integrated Fire Engineering and Response - Fire Brigade Reports and Investigations.

J-F.Cadorin, J-M. Franssen, 2003, A tool to design steel elements submitted to compartment fires-OZone V2. Part 1: pre- and post-flashover compartment fire model, Fire Safety Journal,Volume 38, Issue 5, pages 395-427.

J-F.Cadorin, D. Pintea, J-C.Dotreppe, J-M. Franssen, 2003, A tool to design steel elements submitted to compartment fires-OZone V2. Part 2: Methodology and application,Fire Safety JournalVolume 38, Issue 5, pages 429-451.

J.-M. Franssen, 2005, SAFIR: a thermal/structural program for modeling structures under fire,Eng. Journal, 42 , pages $143-158$.

HaukurIngason, 2009, Design fire curves for tunnels SP Technical Research Institute of Sweden, Box 857, 50115 Borås, Sweden.

ISO EN 834-8:2002 (rev. 2009).

VV.AA., 2002, Handbook of Fire Protection Engineering, Natural Fire Protection Association, Third edition 